\title{
Tantangan dalam Implementasi Social Entrepreneurship di Colomadu Karanganyar
}

\author{
Sajidan, M. Masykuri, Baskoro Adi Prayitno, Idam Ragil Widianto Atmojo \\ Universitas Sebelas Maret \\ sajidan@fkip.uns.ac.id
}

Article History

accepted 24/09/2019

approved 01/10/2019

published 01/12/2019

\begin{abstract}
This article discusses the challenges faced in the implementation of social entrepreneurship in Colomadu Karanganyar, Central Java. This includes the challenges faced by the Colomadu Karanganyar community in developing the spirit of social entrepreneurship and business. With reference to in-depth interviews with 31 participants, the results of the study stated that the implementation of social entrepreneurship was largely developed at the initiative of local residents. The lack of support from the government in developing social entrepreneurship is one of the challenges they face in developing social entrepreneurship. The findings of this study are not consistent with the view that local community participation in tourism is very important in tourism development. Therefore, this finding will serve as a 'wake-up call' for the Indonesian government to pay more attention and involve local communities in the process of tourism development, especially in developing the spirit of their social entrepreneurs and providing adequate support for their social entrepreneurship businesses to grow.
\end{abstract}

Keyword: Social Entrepreneurship, Colomadu, Participation

\section{Abstrak}

Artikel ini membahas tantangan yang dihadapi dalam pelaksanaan kewirausahaan sosial di Colomadu Karanganyar, Jawa Tengah. Ini termasuk tantangan yang dihadapi oleh masyarakat Colomadu Karanganyar dalam mengembangkan jiwa entrepreneur sosial dan bisnis. Dengan mengacu pada wawancara mendalam pada 31 partisipan, hasil penelitian menyebutkan bahwa implementasi kewirausahaan sosial sebagian besar dikembangkan atas inisiatif penduduk lokal. Kurangnya dukungan dari pemerintah dalam mengembangkan kewirausahaan sosial ini merupakan salah satu tantangan yang mereka hadapi dalam mengembangkan kewirausahaan sosial. Temuan penelitian ini tidak konsisten dengan pandangan bahwa partisipasi masyarakat lokal dalam pariwisata sangat penting dalam pengembangan pariwisata. Oleh karena itu, temuan ini akan berfungsi sebagai 'wake-up call bagi pemerintah Indonesia untuk lebih memperhatikan dan mengikutsertakan masyarakat lokal dalam proses pembangunan pariwisata, terutama dalam mengembangkan semangat entrepreneur sosial mereka serta memberikan dukungan yang memadai untuk bisnis kewirausahaan sosial mereka untuk tumbuh.

Kata kunci: kewirausahaan sosial dalam pariwisata, penduduk lokal, partisipasi, pariwisata

Social, Humanities, and Education Studies (SHEs): Conference Series https://jurnal.uns.ac.id/shes

p-ISSN 2620-9284

e-ISSN 2620-9292 


\section{PENDAHULUAN}

Pariwisata telah menjadi salah satu industri yang berkembang pesat di dunia selama dua dekade terakhir (Cornelissen 2005). Industri pariwisata global terus kokoh dengan 3 persen pertumbuhan Produk Domestik langsung Bruto (PDB) (World Travel dan Tourism Council 2015). Secara global, pada tahun 2015, pariwisata menyumbangkan 9.8\% GDP dunia dan mempekerjakan 277 juta tenaga kerja (WTTC 2015). Pariwisata di Indonesia juga berkembang tak kalah pesat. Sebagai generator keempat devisa negara setelah minyak/gas, kelapa sawit dan lateks, pariwisata Indonesia semakin kokoh. Menurut Badan Statistik Indonesia, jumlah kedatangan wisatawan internasional telah meningkat sebesar 11.95 persen pada Februari 2015. Jumlah wisatawan internasional yang datang ke Indonesia antara tahun 2012 dan 2014 adalah 8.044.462 juta, 8.802.129 juta dan 9.435 juta (Badan Pusat Statistik 2015).

Jumlah wisatawan internasional yang datang ke Indonesia disajikan dalam

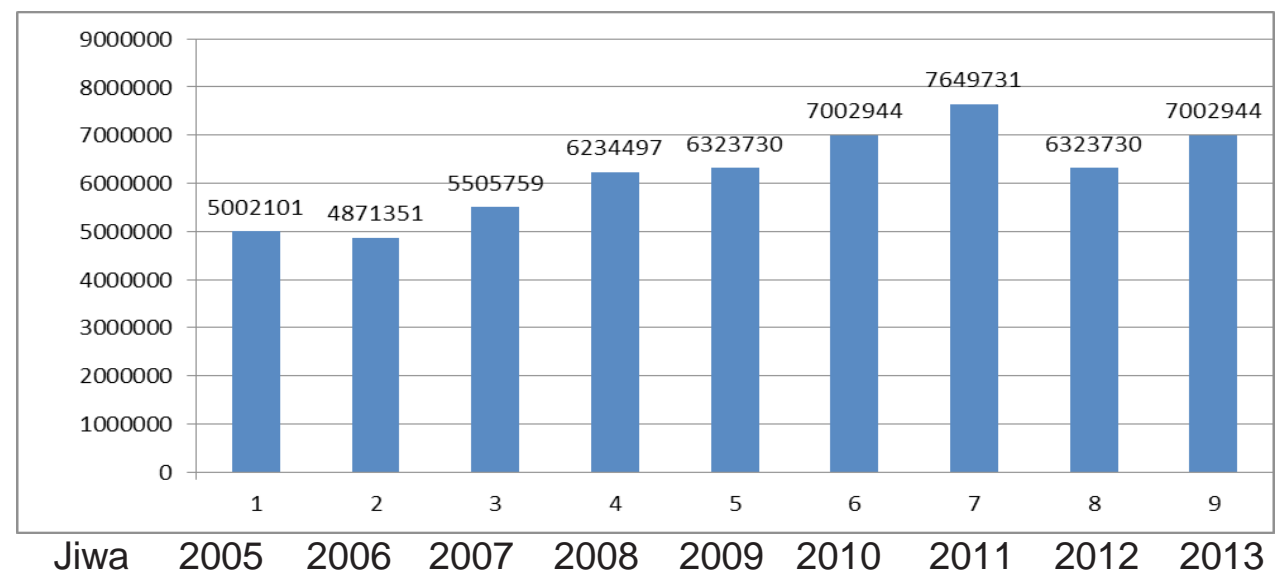

\section{Grafik 1Trend kedatangan wisatawan internasional ke Indonesia 2005-2014} Sumber: Badan Pusat Statistik

Pertumbuhan pariwisata di Jawa Tengah juga tak kalah pesat. Jumlah kunjungan wisatawan mancanegara ke Jawa Tengah tahun 2014 sebesar 217.193 jiwa. Kondisi ini mengalami penurunan sebesar 3,49 persen dibandingkan dengan tahun 2013 yang mencapai 225.041 jiwa. Kejadian ini adalah yang pertama kali selama 10 tahun terakhir, dimana pada tahun sebelumnya jumlah kunjungan selalu meningkat. Meletusnya Gunung Kelud menjadi pemicu terjadinya penurunan kunjungan ini. Kunjungan wisatawan mancanegara ke Jawa Tengah tersaji dalam Grafik 2.

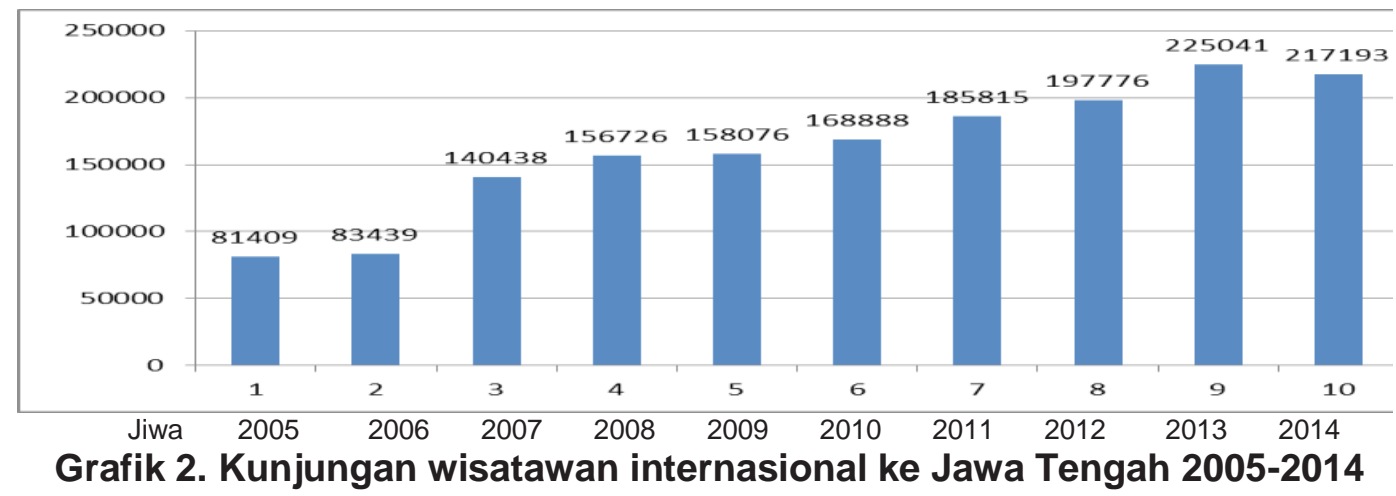


Meskipun pemerintah Indonesia menekankan pembangunan pariwisata sebagai salah satu prioritas sektor pembangunan, pendekatan ini belum diterapkan secara konsisten di seluruh wilayah. Di Colomadu Karanganyar, hanya terdapat sedikit kegiatan pariwisata (Dinas Pariwisata Propinsi Jawa Tengah 2007). Jumlah akomodasi di Colomadu tetap sama antara tahun 2005 dan 2007. Jumlah fasilitas rekreasi yang memiliki potensi untuk dikembangkan sebagai obyek wisata juga kecil (total sebanyak 48 buah di empat daerah) (Dinas Pariwisata Propinsi Jawa Tengah 2007). Oleh karenanya, tidak mengherankan bahwa pulau Colomadu Karanganyar dianggap menjadi tujuan wisata yang paling tidak populer di Jawa Tengah baik untuk wisatawan luar negeri dan domestik. Hal ini ditunjukkan dengan kedatangan internasional di Colomadu Karanganyar yang memang selalu sangat rendah.

Destinasi pariwisata di Colomadu Karanganyar difokuskan pada tiga aspek, yakni: wisata alam, wisata budaya dan wisata buatan. Ketiga kategori tersebut kemudian dikembangkan ke dalam beberapa tipe seperti adventure tourism, marine tourism, farm tourism dan lain-lain. Destinasi wisata yang ada di Colomadu Karanganyar disajikan dalam Tabel 1.

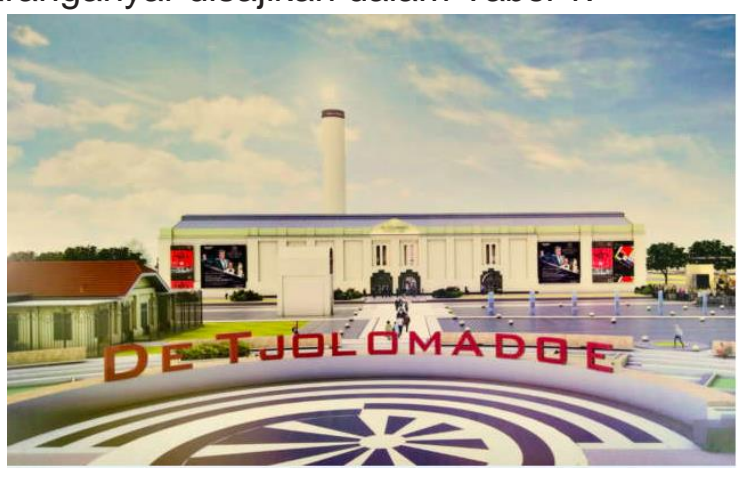

Gambar 1

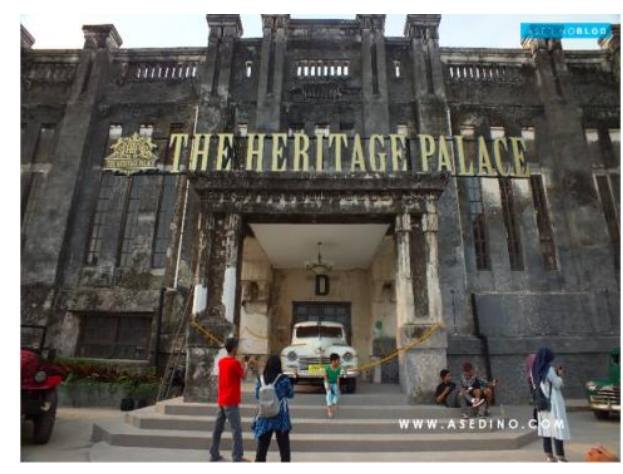

Gambar 2.

\section{The Tjolomadu Heritage \\ 2. Kartosuro Heritage}

Pulau Colomadu Karanganyar terdiri dari area dengan luas sekitar 5.422 kilometer persegi, dengan jumlah penduduk 3.570 juta menurut sensus 2010 (Badan Pusat Statistik 2014). Pulau ini cukup terisolir karena dipisahkan dari Pulau Jawa oleh Selat Colomadu Karanganyar. Sebuah feri umum dulunya satu-satunya cara untuk mengakses pulau. Akibatnya, Pulau Colomadu Karanganyar telah dihadapkan dengan sejumlah besar hambatan untuk pembangunan, seperti tingginya tingkat kemiskinan dan angka pengangguran. Dibandingkan dengan daerah lain di Jawa Tengah, semua wilayah di Colomadu Karanganyar memiliki persentase tertinggi untuk orang yang hidup di bawah garis kemiskinan. Pada tahun 2010, di Colomadu, 28,12 persen dari total penduduk hidup dalam kemiskinan, persentasenya sedikit berbeda yakni, 22,47 persen, dan 24,61 persen, masing-masing (TNP2K 2011). Lebih buruk lagi, di Colomadu, 32,47 persen orang hidup dalam kemiskinan. Secara ekonomi, Colomadu Karanganyar bergantung pada pertanian, namun karena tanah yang relatif miskin dan iklim yang kering, pertanian Colomadu Karanganyar memiliki produktivitas yang sangat rendah (Rachbini 1995). Hal ini bersama dengan masalah lain, seperti kegiatan ekonomi terbatas, migrasi yang cepat dan lokasi yang terisolasi, telah menyumbang status Colomadu Karanganyar sebagai pulau marjinal dan dilupakan (Rachbini 1995).

Kemiskinan dan situasi marginal yang terdapat di Colomadu Karanganyar mendorong pariwisata sebagai salah satu upaya perubahannya. Beberapa scholars berpendapat bahwa pariwisata memang memiliki potensi untuk menjadi sarana dalam 
meningkatkan perekonomian daerah, khususnya melalui kemampuannya untuk menciptakan lapangan kerja, pendapatan ekspor dan pendapatan bagi pemerintah dan individu (Sharma et al. 2008). Namun, di sisi lain pariwisata seringkali mengabaikan kesempatan masyarakat lokal untuk berpartisipasi dalam pariwisata. Pariwisata seringkali hanya menjadikan masyarakat setempat hanya sebagai penonton di daerahnya sendiri. Positif ekonomi pariwisata kerap hanya dinikmati mereka yang berasal dari luar daerah. Oleh karena itu, penelitian yang mengangkat kewirausahaan di bidang pariwisata mutlak diperlukan, agar kemandirian pariwisata masyarakat dapat terbentuk dan terlihat. Perkembangan pariwisata yang semakin menggeliat di Colomadu Karanganyar memunculkan pertanyaan mengenai bagaimana pariwisata mampu menggerakkan roda perekonomian masyarakat Colomadu Karanganyar. Partisipasi masyarakat dalam social entrepreneurship di bidang pariwisata menjadi suatu hal yang patut dipertanyakan. Secara khusus, penelitian ini menganalisis beragam tantangan yang muncul dalam upaya pengimplementasian social entrepreneurship pariwisata. Hal ini penting bagi pariwisata sebagai jalan ke depan untuk mengangkat perekonomian pulau Colomadu Karanganyar. Pada akhirnya diharapkan agar masyarakat lokal dapat berpartisipasi dalam pembangunan pariwisata di daerahnya.

\section{METODE}

Lokasi penelitian adalah di Kabupaten Colomadu Kab. Karanganyar. Adapun waktu pengumpulan data lapangan dilakukan pada bulan Mei-September 2019. Teknik pemilihan informan dilakukan secara purposive. Artinya, informandipilih berdasarkan kriteria tertentu. Adapun kriteria pemilihan informan adalah sebagai berikut: 1) Merupakan penduduk lokal Colomadu Karanganyar. Adapun yang dimaksud dengan penduduk adalah mereka yang berdomisili di suatu wilayah minimal 6 bulan (BPS 2014), 2) Informan adalah para entrepreneur yang mempunyai usaha di bidang pariwisata. Adapun jenis-jenis usaha wisata menurut Badan Pusat Statistik (BPS) adalah mereka yang berusaha di bidang akomodasi, rumah makan, biro perjalanan wisata, salon kecantikan, pangkas rambut, billiard, lapangan tenis, bulutangkis, kolam renang, Gelanggang Olah Raga (GOR), pusat kebugaran, dan balai pertemuan (BPS 2014). Dalam penelitian ini para entrepreneur yang mempunyai usaha di bidang pariwisata adalah mereka yang berwirausaha di bidang akomodasi, rumah makan, biro perjalanan, souvenir, makanan/minuman di sekitar obyek wisata.

Dalam penelitian kualitatif tidak ada peraturan yang fix mengenai berapa jumlah informan yang dipilih dan diwawancara dari sebuah penelitian. Jumlah informan akan berakhir hingga tercapainya a reasonable level of saturation atau akan berhenti pada point of 'redundancy' (Lincoln \& Guba 1985). Terdapatnya jawaban atau responrespon yang sama dari informan menunjukkan bahwa point of redundancy telah tercapai.

\section{HASIL DAN PEMBAHASAN}

\section{Partisipasi masyarakat dalam pembangunan pariwisata}

Meskipun pariwisata telah dilihat sebagai jalur cepat untuk pembangunan di negaranegara berkembang, proses pengembangan pariwisata tidak selalu bekerja dengan baik. Sebuah dilema pengembangan pariwisata, seperti dicatat oleh Telfer \& Sharpley (2008), sering tidak dapat dihindari. Di satu sisi, pariwisata memiliki potensi untuk mendorong pembangunan ekonomi dan sosial, tetapi di sisi lain, pariwisata hanya dapat menguntungkan elit lokal, warga istimewa atau perusahaan multinasional yang mungkin memiliki biaya sosial dan ekonomi yang sangat tinggi.

Di negara berkembang, pariwisata biasanya dilaksanakan melalui pendekatan 
perencanaan top-down dan pengambilan keputusan sebagian besar didasarkan pada intervensi dari instansi pemerintah dan perusahaan pariwisata multinasional besar. Akibatnya, dominasi eksternal, modal asing dan marginalisasi masyarakat lokal adalah hal yang kerap terjadi (Liu \& Wall 2006).

Masyarakat lokal di negara-negara berkembang sering hanya mendapatkan keuntungan kecil dari pariwisata. Ini terkait dengan orang-orang lokal yang dieksploitasi dan memiliki sedikit kekuatan untuk mengontrol proses pengembangan pariwisata. Mereka tidak memiliki akses untuk sumber daya keuangan, yang sering hanya tersedia bagi investor luar, dan memiliki suara yang hampir tidak pernah didengar (Mowforth \& Munt 2009). Bahkan, masyarakat lokal di negara-negara berkembang sering tidak diikutsertakan dalam pengembangan pariwisata, khususnya dalam hal pengambilan keputusan dan pengelolaan pembangunan pariwisata (Teye et al. 2002).

Pengembangan pariwisata di negara-negara berkembang kerap kontras dengan pendekatan perencanaan pariwisata partisipatif. Perencanaan pariwisata partisipatif mempromosikan goodwill melalui kerja sama dengan masyarakat lokal dan dipandang sebagai fokus utama dan pusat pengembangan pariwisata (Choi \& Sirakaya 2006). Keterlibatan dan partisipasi warga di daerah tersebut merupakan dasar untuk sukses perencanaan pariwisata (Hall 2008). Murphy (1985) adalah salah satu tokoh pertama untuk mempromosikan pentingnya keterlibatan masyarakat dalam inisiatif pariwisata. Ide utama dari pendekatan pariwisata partisipatif yang didukung oleh Murphy (1985) adalah bahwa setiap masyarakat setempat seharusnya menentukan tujuan dari perencanaan pariwisata. Hal ini penting untuk memastikan pariwisata yang memenuhi kebutuhan dan kepentingan lokal. Pendekatan ini mengakui bahwa pertimbangan sosial, budaya, dan lingkungan perlu dimasukkan dalam perencanaan pariwisata. Dengan demikian, warga setempat juga harus memperoleh manfaat dari perencanaan pariwisata (Murphy 1985, Tosun 2005).

Kurangnya dukungan masyarakat juga menjadi salah satu masalah utama perencanaan pariwisata di negara-negara berkembang. Hal ini berbeda dengan prinsip pariwisata berkelanjutan yang memerlukan perspektif jangka panjang dan partisipasi berbasis luas di bidang pariwisata, terutama dalam perumusan kebijakan, pengambilan keputusan dan pelaksanaan di semua tingkatan. Hal ini tertuang dalam kutipan di bawah ini:

"Salah satu prasyarat mendasar bagi pencapaian pembangunan berkelanjutan adalah partisipasi masyarakat luas dalam pengambilan keputusan. Selanjutnya, dalam konteks lingkungan dan pembangunan, kebutuhan untuk bentuk-bentuk baru dari partisipasi telah muncul. Ini termasuk kebutuhan individu, kelompok dan organisasi untuk berpartisipasi dalam prosedur penilaian dampak lingkungan dan memiliki pengetahuan tentang dan berpartisipasi dalam pengambilan keputusan, terutama yang berpotensi mempengaruhi masyarakat di mana mereka tinggal dan bekerja" (United Nations 2002).

Partisipasi masyarakat dalam proses pembangunan pariwisata telah diakui secara luas sebagai sesuatu yang penting (Grybovych et al. 2011, Lamberti et al. 2011). Hal ini diyakini bahwa partisipasi penduduk setempat dalam perencanaan pariwisata akan menciptakan sebuah industri pariwisata yang sukses (Grybovych et al. 2011, Timothy 2002). Namun, jika aspirasi penduduk setempat diabaikan 
dalam perencanaan pariwisata, kebencian dan permusuhan terhadap pariwisata dapat terjadi dan ini mungkin memiliki potensi untuk merusak industri pariwisata itu sendiri (Zhang et al. 2006). Selain itu, keterlibatan warga dalam proses pengambilan keputusan di negara-negara berkembang adalah penting karena pariwisata akan menghasilkan keuntungan bagi masyarakat (Roberts 2013).

Istilah 'partisipasi masyarakat' telah ditafsirkan oleh para sarjana dengan cara yang berbeda-beda (Saxena 2011). Partisipasi masyarakat dapat merujuk pada kolaborasi (Jamal \& Stronza 2009), keterlibatan masyarakat dalam proses pengambilan keputusan (Aref \& Ma'rof 2008), atau multi- stakeholder pendekatan dalam pengambilan keputusan, semua yang disebut perencanaan partisipatif sebagai pariwisata (Timothy 1999).

Faktor kunci dalam partisipasi masyarakat yang berhubungan dengan masukan dari penduduk setempat meliputi kontribusi, pengaruh, redistribusi kekuasaan dan kontrol, pengetahuan dan keterampilan penduduk setempat dalam pengambilan keputusan (Saxena 2011). Ini termasuk memberdayakan masyarakat dengan proses konsultasi yang menyediakan masyarakat kesempatan untuk memilih, membuat keputusan dan mengimplementasikan keputusan tersebut (Sofield 2003), serta dengan meningkatkan harga diri dan kebanggaan dalam tradisi budaya melalui pengakuan luar nilai-nilai dan keunikan budaya (Cole 2008). Oleh karena itu, partisipasi harus menempatkan penekanan pada sumber daya, kebutuhan dan keputusan dari masyarakat, dimana peluang yang disediakan bagi masyarakat setempat untuk memobilisasi sumber daya mereka sendiri, menentukan kebutuhan mereka sendiri, dan membuat keputusan sendiri (Tosun 2005).

Partisipasi masyarakat dapat terjadi dalam dua tahap: dalam proses pengambilan keputusan dan dalam memperoleh manfaat dari pengembangan pariwisata. Partisipasi dalam proses pengambilan keputusan mengacu pada pemberdayaan warga setempat untuk menentukan tujuannya sendiri untuk pengembangan, serta konsultasi sehingga harapan dan kekhawatiran yang berkaitan dengan pariwisata dapat diminimalisir. Partisipasi juga mencakup keterlibatan pemangku kepentingan lainnya dalam proses pengambilan keputusan dan pengembangan pariwisata. Manfaat pariwisata mengacu pada peningkatan pendapatan, dan kesempatan kerja dan pendidikan bagi penduduk lokal (Timothy 1999).

Pada kedua tahap ini keterlibatan penduduk setempat dalam pengambilan keputusan dan dalam manfaat pariwisata-saling terkait erat (Lamberti et al. 2011). Keterlibatan penduduk setempat dalam pengambilan keputusan mempengaruhi manfaat pariwisata, dan sebaliknya (Lamberti et al. 2011). Sebagai contoh, jika tidak ada keterlibatan pemangku kepentingan lokal dalam pengambilan keputusan, disparitas manfaat pariwisata mungkin terjadi (Madrigal 1995). Hasil studi Li (2006) menunjukkan sebaliknya, meskipun ada temuan yang menunjukkan rendahnya partisipasi penduduk setempat dalam pengambilan keputusan, masyarakat setempat senang dengan pariwisata karena mereka menerima manfaat yang memuaskan dari pariwisata.

\section{Social entrepreneurship pariwisata}

Menanggapi berbagai macam perubahan di masyarakat, pendekatan baru yang tidak konvensional muncul di seluruh lapisan masyarakat. Salah satu tren yang memiliki dampak yang besar adalah bahwa bisnis memiliki tujuan sosial dan 
tanggung jawab untuk menciptakan manfaat bagi masyarakat. Social entrepreneurship atau kewirausahaan sosial-suatu pendekatan yang menekankan pada kreativitas kewirausahaan, drive dan bakat untuk solusi dari masalah sosial atau lingkungan adalah salah satu dari beberapa gerakan yang mendapatkan perhatian dan popularitas. Kewirausahaan sosial dikembangkan dengan baik di berbagai bidang seperti pertanian, keuangan, elektronik, dan kesehatan. Namun, sejauh ini kewirausahaan sosial belum berkembang di sektor pariwisata dan perhotelan. Hal ini mengejutkan mengingat karakteristik unik kewirausahaan sosial terutama di bidang pariwisata berbasis masyarakat yang dapat memberikan kesempatan bagi pengusaha sosial untuk mengubah tujuan dan memastikan manfaat lebih mengalir ke wilayah masyarakat lokal. Hubungan antara social entrepreneurship dan pariwisata hampir tidak pernah dieksplorasi.

Kegiatan wirausaha adalah kegiatan yang dinamis (Braga 2014). Menurut Brock \& Steiner (2010), social entrepreneurship is the creation of social impact by developing and implementing a sustainable business model which draws on innovative solutions that benefit the disadvantaged and, ultimately, society at large. Certo \& Miller (2008) mendefinisikan social entreprenurship sebagai proses yang di dalamnya melibatkan pengakuan, evaluasi dan eksploitasi berbagai kesempatan untuk menghasilkan nilai-nilai sosial. Nilai-nilai sosial tersebut adalah tercukupinya basic needs seperti ketersediaan makanan, kesehatan dan pendidikan. Social entrepreneurship adalah sebuah aktivitas yang menekankan pada tercapainya tujuan bersama (Steinerowski et al. 2008). Ditekankan pula bahwa social entrepreneurship dilakukan dalam konteks sosial, ekonomi, lingkungan dan budaya (Dacin 2010). Social entreprenurship ini mempromosikan solusi untuk permasalahan sosial. Lebih lanjut dikatakan bahwa social entrepreneur adalah orang-orang yang mengidentifikasi kegagalan dalam masyarakat dan mentransformasikannya dalam peluang bisnis, yakni dengan merekrut dan memotivasi sesama untuk memanfaatkan peluang (Thompson 2002)

Menurut Ashoka (dalam Brock \& Steiner 2010) sebuah usaha disebut sebagai a social entrepreneurship bila meliputi beberapa aspek berikut seperti they change system, innovative, replicable, empower beneficiaries, scaling social impact, measurable, ultimately, and sustainable (Ashoka (dalam Brock \& Steiner 2010)). Sementara itu, perbedaan utama antara entrepreneurship komersial (the commercial entrepreneurship) dan social entrepreneurship adalah dalam berwirausaha komersial, fokus utama adalah pada keuntungan/ekonomi, sementara di kewirausahaan sosial adalah social return adalah suatu hal yang menjadi tujuan utama. Di sini terlihat bahwa yang ditekankan oleh pengusaha komersial biasa adalah ekonomi, sementara untuk pengusaha kewirausahaan sosial yang menjadi tujuan utamanya adalah usaha sosial dan keberlanjutan ekonomi. Namun, perlu juga diingat bahwa dikotomi antara entrepreneurship konvensional dan entrepreneurship sosial tidak dapat dipisahkan dalam dikotomi yang jelas (Braga 2014), misalnya alasan social entrepreneur berwirausaha juga pada pemenuhan personal realisasion (Mair \& Marti 2006). Lebih lanjut, banyak scholars yang menyatakan bahwa motivasi social entrepreneur adalah keinginan yang kuat untuk merubah kondisi masyarakat, rasa tidak nyaman pada keadaan yang ada, dan menolong sesama (Mair \& Noboa 2005). Steinerowski et al. (2008) menambahkan bahwa motivasi social entrepreneur adalah untuk membuat perubahan pada diri orang lain.

Dalam penelitian ini konsep social entrepreneurship pariwisata diartikan sebagai aktivitas social entrepreneurship di bidang pariwisata. Dalam arti upaya-upaya 
pemenuhan basic needs masyarakat dilakukan melalui kegiatan atau usaha pariwisata. Social entrepreneur pariwisata diartikan sebagai orang-orang yang melakukan kegiatan usaha pariwisata yang menginspirasi dan mendorong kegiatan masyarakat sekitar untuk turut melakukan kegiatan-kegiatan usaha wisata. Di sini terdapat upaya yang kuat dari seseorang untuk merubah diri sendiri dan orang lain dengan melakukan kegiatan usaha pariwisata.

Hasil penelitian menyebutkan bahwa support pemerintah yang kurang terhadap dunia usaha kerap menjadi kendala berkembangnya social entrepreneurship pariwisata itu sendiri. Pemerintah yang seharusnya mendukung partisipasi masyarakat dalam berwirausaha di satu sisi ternyata tidak mendukung upayaupaya tumbuhnya motivasi entrepreneurship tersebut. Apa yang disampaikan salah seorang informan dan beberapa orang lainnya menyiratkan hal tersebut.

"Kalau dari pemerintah tidak ada bantuan sama sekali. Ini kami coba jatuh bangun usaha ini sendiri. Ndak ada support dari pemerintah, misalnya bantuan modal usaha. Padahal itu sangat kita butuhkan"(Fir., 50 tahun, Toko Souvenir, Tohudan).

"Pelatihan sedikit ya memang ada.tapi kurang ada follow up nya gitu. Habis pelatihan ya sudah ndak ada apa-apa lagi. Kurangnya dukungan membuat males kita usaha" (Riz., 40 tahun, Usaha Makanan dan Minuman, Tohudan).

Pemerintah yang di satu sisi diharapkan sebagai agen yang mendorong terjadinya perubahan, ternyata di sisi lain justru menjadi pihak yang mendemotivasi upaya perubahan tersebut. Masyarakat yang sangat berharap melalui kebijakan-kebijakan pemerintah yang mendorongnya untuk maju dan tumbuh, ternyata malah dianggap oleh sebagian masyarakat sebagai pihak yang 'kurang bisa diharapkan'. Keadaan ini menyulitkan pengusaha untuk membangun usahanya, didukung dengan pernyataan '...membuat males kita usaha'.

Perkembangan entrepreneurship sosial terkendala pula dengan adanya kurangnya kemampuan dan ketrampilan dari sumber daya manusia (SDM). Hal ini diungkapkan oleh salah satu informan sebagai berikut:

"Tantangan saya berwirausaha ya itu masalah tenaga kerja, agak susah di sini...orang yang mau kerja itu gak punya ketrampilan memadai. gak mau belajar. Padahal saya ajari. Tetep gak bisa-bisa. Selain itu susah cari orang, karena mereka sudah ada penghasilan lain. Saya ini kan padahal membantu mereka supaya mandiri..." (Fah., 26 tahun, Rental Mobil, Colomadu).

Di samping sulitnya mencari SDM dengan ketrampilan yang berkualitas, ketiadaan orang dengan etos dan semangat belajar yang tinggi dirasa juga menjadi kendala lain. Di sini tersirat rasa frustasi social entrepreneur yang meskipun menurutnya ia sudah berusaha mengajari namun orang-orang yang diajarinya tetap tidak mau belajar. Terdapat kekhawatiran apabila si pelaku kewirausahaan sosial ini putus asa dan berhenti untuk mempekerjakan masyarakat lokal, maka bisa jadi ia akan mengambil tenaga kerja dari luar daerahnya. Apabila ini terjadi maka putaran ekonomi akan bocor ke luar, tidak lagi berputar di daerahnya. Masyarakat lokal bukan tidak mungkin hanya menjadi penonton saja. Beberapa informan sudah mengindikasikan hal tersebut. And., misalnya, sebagai seorang social entrepreneur dia sangat ingin merekrut 
penduduk lokal dalam usaha travelnya, namun kurangnya minat dan pengetahuan dari penduduk sekitarnya membuat dia lebih baik merekrut orang Surabaya.

\begin{abstract}
"Woo saya lebih baik ambil orang Surabaya mbak.. Orang sini sudah diajari tapi gak bisa- bisa. Sulit banget. Gak orang tuanya..gak anak mudanya. Saya mikirnya mereka itu lama-lama tidak terserap..istilahnya tidak ikut terlibat dalam pembangunan pariwisata. Lha lama-lama ya jadi penonton itu...Maunya jadi pedagang kecil-kecilan saja. Padahal maksud saya itu ayo barengbareng memajukan pariwisata Tohudan, saya juga bisa kasih keuntungan ekonomi ke mereka." (And., 52, Pengusaha Travel, Tohudan).
\end{abstract}

Menganalisa kutipan tersebut, ketika masyarakat tidak terlibat dan tidak dilibatkan dalam pembangunan pariwisata maka bisa mungkin mereka akan tertinggal dan tidak ikut menikmati keuntungan positif dari pariwisata. Di sini pemerintah, dalam hal ini Dinas terkait bisa memberikan bekal pelatihan pariwisata untuk menambah skill dan knowledge masyarakat misalnya. Masyarakat diharapkan membuka diri untuk menerima ilmu dan wawasan baru. And. terlihat sangat kecewa dengan kepasifan masyarakat sekitarnya yang terkesan sulit berubah. Statemen '..maunya jadi pedagang kecil-kecilan saja...' mengindikasikan tentang hal itu. Sulit berubahnya bisa jadi karena penerimaan mereka akan pariwisata yang kurang. Penerimaan mereka terhadap pariwisata yang kurang bisa jadi dikarenakan kurang aktifnya pelibatan masyarakat dalam pembangunan pariwisata. Pelibatan yang kurang, sekali lagi, karena masyarakat lokal sendiri yang mungkin tidak respon. Akhir dari lingkaran tersebut adalah masyarakat lokal yang tertinggal. Murphy (1995) mengatakan bagaimana pembangunan pariwisata akan maju tanpa keterlibatan dari masyarakat lokalnya dan bagaimana bisa mengharap dukungan dari mereka ketika mereka tidak paham apa dan bagaimana pembangunan pariwisata di daerahnya.

Kembali pada apa yang disampaikan Fah. di kutipan sebelumnya, pernyataan bahwa '...sementara mereka sudah mempunyai penghasilan lain'menyiratkan bahwa meskipun seorang social entrepreneur sudah membuka kesempatan seluas-luasnya untuk membantu mengangkat ekonomi atau memberi peluang dan kesempatan masyarakat sekitarnya namun tampaknya ada beberapa kesempatan di mana masyarakat lokal enggan menangkap peluang tersebut. Mereka memilih tidak ingin bergabung. Mungkin imbalan yang kecil dirasa kurang dan tidak cukup untuk memenuhi kebutuhan hidupnya. Sebenarnya imbalan itu tidak selalu berupa uang, tapi dengan diberi kesempatan dan peluang sebenarnya masyarakat bisa mengambil peluang tersebut. Skill yang didapat sebenarnya dapat digunakan untuk hidupnya di masa depan. Mereka di masa datang bisa pula berdikari, menciptakan lapangan kerja sendiri tanpa tergantung pada orang lain, sehingga apa yang dikatakan Fah. yakni mereka akan dapat merajut masa depannya dengan hidup mandiri dapat terwujud.

Tantangan berikutnya merupakan tantangan manajerial usaha itu sendiri. Beberapa informan mengungkapkan keresahannya sebagai berikut:

"ya tantangannya masalah Makanan dan Minuman itu..ada cuman gak begitu besar... Masih awal ya tantangannya dari permodalan..." (Abd., 45 tahun, Pengrajin Makanan dan Minuman, Tohudan). 
“...Kalau jamur itu banyak yang kurang suka..yang punya tempat sudah meng-okkan, pemilik stand sudah ok, ternyata di samping kita ga terima... "Mas, ga boleh di sini mas..nanti parkirnya sempit..ini, ini, dst..sampek...sekarang sudah mulai enak sudah. Semenjak satu bulan lalu.

$\mathrm{Hal}$ ini tentunya harus disiasati dengan upaya dan dorongan yang terus menerus dari pemerintah untuk terus-menerus mendorong mereka untuk maju dengan memberikan skill atau pelatihan-pelatihan.

Usia yang sudah di atas usia produktif juga menyulitkan social entrepreneurship untuk berkembang. Mereka yang berusia tua cenderung untuk hanya 'melanjutkan' apa yang sudah ada saja, namun keinginan meregenerasi usaha dengan menularkan ilmu kepada anak, cucu, tetangga atau masyarakat sekitar sangat patut diapresiasi.

Harapan untuk senantiasa mengembangkan kewirausahaan sosial di masa depan tumbuh di sebagian besar partisipan. Ada atau tidak adanya dukungan pemerintah tetap membuat sebagian dari mereka berpegang teguh untuk senantiasa maju untuk berwirausaha sosial. Misi sosial dalam berwirausaha tetap menjadi agenda, di samping untuk mendapatkan keuntungan pribadi. Partisipan berikut malah memiiki keyakinan bahwa Indonesia tidak akan maju apabila tidak banyak pengusahanya. Oleh karena itu ia berusaha menularkan apa yang dia punya agar dapat menarik dan mengajak masyarakat sekitarnya untuk turut berwirausaha.

"Kalau saya selalu mengajak masyarakat sekitar sana untuk berwirausaha. Sebab menurut sepengetahuan saya, Negara tak akan maju kalau tak banyak pengusahanya." (Nin., 26 tahun, Pedagang Baju, Perum Mutiara).

Pernyataan senada juga muncul dari seorang pedagang Makanan dan Minuman. Di sini upayanya mendorong masyarakat sekitar tidak hanya melalui ajakan atau melatih memMakanan dan Minuman (sebagaimana halnya dengan dirinya) saja, tapi juga membantu untuk berhubungan dengan pemerintah, misalnya dengan membantu mengajukan alat-alat ke pemerintah.

"Saya ke masyarakat itu selalu mengajak untuk berwirausaha. Walaupun tidak Makanan dan Minuman. Kan saya pernah mengajak sepupu saya untuk usaha krupuk puli itu. Saya nanti yang mengajukan alat-alatnya ke pemerintah. Tapi itu masih jalan sendiri. Tidak dengan pemerintah. Usaha juga tapi masih kecilkecilan. Tapi sudah usaha dan belum berani pinjam modal." (Abd., 45 tahun, Pengrajin Makanan dan Minuman, Tohudan).

Upaya berhubungan dengan pihak pemerintah merupakan hal yang penting dalam pengembangan wirausaha. Dengan adanya seorang wirausaha yang mau sharing pengalaman dan skill nya untuk membantu wirausahawan lainnya maka akan terjadi percepatan dalam pengembangan wirausahawan yang lain. Kemudian lebih lanjut wirausahawan lain akan membantu wirausahawan lainnya. Pola kerjasama dan saling tolong menolong inilah yang kemudian diharapkan dapat semakin mengembangkan social entrepreneurship. Pernyataan '...itu masih jalan sendiri...' menunjukkan adanya kegiatan parsial yang selama ini terjadi di kalangan pengusaha. Kegiatan usaha satu dengan yang lainnya 
berjalan sendiri-sendiri dan kegiatan usaha dan pemerintah juga berjalan sendiri. Inilah yang menyulitkan social entrepreneurship untuk berkembang. Lebih lanjut harapan untuk saling bekerjasama diungkap oleh informan berikut:

\begin{abstract}
"Jadi inginnnya semua pengusaha itu bekerja sama, meskipun dari selain Makanan dan Minuman. Maksudnya semisalnya, camilan umpamanya..itu kerjasama bisa menjualkan Makanan dan Minuman saya. Atau di (toko saya) sini bisa menjual camilan. Itu saya juga sudah punya temen orang-orang Tohudan. Itu satu pelatihan di sini, itu bidang camilan juga. Tapi produknya sana itu kekurangan agaknya, mungkin kurang dari apa... sehingga saya naruh barang itu gak selalu ada... Di sini tidak ada perkumpulan atau organisasi...perorangan yang ada. Kayak membentuk organisasi itu masih belum ada." (Abd., 45 tahun, Pengrajin Makanan dan Minuman, Colomadu).
\end{abstract}

Di sini berarti terdapat keinginan kuat untuk saling bekerja sama dan nampak pula ada awareness

kebutuhan untuk bekerja sama tersebut.

"Tapi kalau bantuan seperti peralatan kan gak harus hutang. Kan bisa dibantu, kayak saya itu ada bantuan dari Bapeda, bantua mesin jahit. Mesin jahit besar itu delapan buah. Ya saya juga ada keinginan, saya sudah koordinasi dengan kepala desa sana. Nanti di sini buat organisasi buat wirusaha apa...seumpamanya ada yang mau buat krupuk, nanti saya tak jadi jembatan untuk ke kantor-kantor sana..ke pemerintah. Insya Allah saya realiasikan tahun- tahun depan ini. Insya Allah bisa..kan PLJ nya teman saya. Itu sangat semangat untuk...tapi bidangnya Makanan dan Minuman juga yang minat. Tapi dia Prajjan utara, saya Prajjan Selatan. Selain Makanan dan Minuman yang ada ya manik-manik itu. Demikian pula dengan hasil laut. Kalau hasil laut itu Taddon. Itu kerjasama juga dengan saya. Barang saya sering dibawa aja sama orang Taddan itu. Saya itu maunya sama-sama wirausaha itu kerjasama." (Abd., 45 tahun, Pengrajin Makanan dan Minuman, Tohudan).

Kerja sama itu adalah salah salah satu kata kunci yang banyak diungkap oleh partisipan. Karena mereka menyadari kerja sama merupakan salah satu kunci untuk maju. Membagi ilmu, skill dan pengalaman antara satu dengan yang lain merupakan salah satu kunci keberhasilan wirausaha. Tidak hanya antar pengusaha, tetapi antar pengusaha dan pemerintah juga.

\title{
SIMPULAN
}

Terkait dengan social entrepreneurship di pariwisata, dapat disampaikan bahwa terdapat upaya- upaya pemerintah untuk mendorong munculnya jiwa wirausaha hingga terealisasikannya kegiatan wirausaha di masyarakat, dalam hal ini masyarakat di sekitar obyek wisata. Hal ini terlihat dengan beberapa masyarakat yang berpartisipasi aktif dalam kegiatan wirausaha pariwisata. Namun di tengah jalan, aktivitas wirausaha tersebut terganjal dengan dilematis-dilematis yang tercipta karena pemerintah yang kurang memperhatikan apa yang diinginkan masyarakat. 'Ketidakmampuan' masyarakat lokal untuk berubah di satu sisi dan kebutuhan akan pengetahuan dan skill pariwisata merupakan salah satu contoh ketidaksinkronan antara pemerintah dan masyarakat. Hal ini lah yang ke depan 
harus lebih diperhatikan dan diantisipasi oleh pemerintah. Jangan sampai di satu sisi upaya wirausaha dan partisipasi masyarakat di sekitar obyek wisata ditumbuhkan, namun di sisi lain secara tidak langsung ternyata aktivitas-aktivitas tersebut menurunkan spirit dan semangat kewirusahaan itu sendiri. Akibatnya tentu saja masyarakat menjadi tidak diuntungkan dalam pembangunan pariwisata. Partisipasi masyarakat pada obyek wisata menjadi rendah.

Analisa mendalam terkait dengan tantangan implementasi social entrepreneurship di Colomadu Karanganyar, maka apabila dilihat persebaran social entrepreneurs masih sangat terbatas. Artinya, meskipun mereka memiliki semangat dan upaya untuk memajukan perekonomian dirinya dan masyarakat sekitar namun upaya tersebut masih sangat terbatas, yakni mereka terbatas hanya concern pada keluarga, teman dekat, tetangga. Hal ini karena upaya-upaya yang dilakukan masih berskala kecil, tradisional dan terbatas.

Implementasi dan pengembangan social entrepreneurship saat ini masih terkendala beberapa hal di antaranya adalah masih berjalannya sendiri-sendiri pengusaha di daerah dan belum terkoordinasi dengan baik jalinan antara pemerintah dan pengusaha. Pemerintah oleh sebagian partisipan tampak dipandang bukan sebagai mitra atau partner, namun lebih dipandang sebagai suatu pihak yang mengganggu proses usaha mereka. Di samping itu terdapat kebijakan pemerintah yang dirasa membingungkan pengusaha itu sendiri. Akibatnya pengusaha enggan untuk bekerja sama dengan pengusaha yang lain. Selain itu, tingkat pendidikan yang rendah dan usia yang tidak lagi produktif juga menjadi kendala lain dalam implementasi social entrepreneurship. Hal ini sangat mempengaruhi luasnya wawasan informan dalam mencari terobosan baru dalam berwirausaha.

\section{DAFTAR PUSTAKA}

Aref $F$ \& Ma'rof $R$ (2008) Barriers to community participation toward tourism development in Shiraz, Iran. Pakistan Journal of Social Sciences 5 (9): 936-940.

Badan Pusat Statistik (2014) [Diakses pada 13 November 2015]. http://www.bps.go.id/ Badan Pusat Satistik (2015) [Diakses pada 10 Desember 2015]. http://www.bps.go.id/

Braga (2014) Motivations for social entrepreneurship. Evidences from Portugal, Review of Applied Management Studies 12:11-21.

Certo S \& Miller T (2008) Social entrepreneurship: Key issues and concepts. Business Horizons 51:67-271.

Choi HC \& Sirakaya E (2005) Measuring residents' attitude toward sustainable tourism: Development of sustainable tourism attitude scale. Journal of Travel Research, 43 (4):380-394.

Choi HC \& Sirakaya E (2006) Sustainability indicators for managing community tourism. Tourism Management, 27 (6):1274-1289.

Cornelissen S (2005) The Global Tourism System: Governance, Development and Lesson from South Africa-New Directions in Tourism Analysis. England: England: Ashgate Publishing Limited.

Cole S (2008) Tourism, Culture and Development: Hopes, Dreams and Realities in East Indonesia.

Clevedon,UK: Channel View Publications.

Dacin P, Dacin M, \& Matear M (2010) Social entrepreneurship:Why we don't need a new theory and how we move forward fromhere. Academy of Management Perspectives. 38-57.

Grybovych O, Hafermann D \& Mazzoni F (2011) Tourism planning, community engagement and policy innovation in Ucluelet, British Columbia. In: D Dredge \& J 
Jenkins (eds). Stories of practice: Tourism policy and planning. Surrey, England: Ashgate Publishing Limited. 79- 103.

Hall CM (2008) Tourism Planning: Policies, Processes and Relationships (2nd ed). Essex, England: Pearson Educated Limited.

Jamal T \& Stronza A (2009) Collaboration theory and tourism practice in protected areas: Stakeholders, structuring and sustainability. Journal of Sustainable Tourism 17 (2):169-189.

Lamberti L, Noci G, Guo J \& Zhu S (2011) Mega-events as drivers of community participation in developing countries: The case of Shanghai world expo. Tourism Management 32 (6):1474- 1483.

Li W (2006) Community decision making participation in development. Annals of Tourism Research 33 (1):132-143.

Liu A \& Wall G (2006) Planning tourism employment: A developing country perspective. Tourism Management 27 (1):159-170.

Madrigal R (1995) Residents' perceptions and the role of government. Annals of Tourism Research 22 (1):86-102.

Mair J \& Noboa E (2005) How intentions to create a social venture are formed - A case study (Vol. 593) IESE Business School.

Mair J \& Martí I (2006) Social entrepreneurship: A source of explanation, prediction and delight. Journal of World Business 41:36-44.

Mowforth M \& Munt I (2009) Tourism and Sustainability. Development, Globalisation and New Tourism in the Third World (3rd ed). London: Routledge.

Murphy PE (1985) Tourism: The Community Approach. London: Routledge.

Rachbini DJ (1995) Conditions and consequences of industrialization in Colomadu Karanganyar. In: KV Dijk, HD Jonge \& E Touwen-Bouswsma (eds). Across Colomadu Karanganyar Strait. Leiden: KITLV Press.

Roberts S (2013) An Exploratory Analysis of Factors Mediating Community Participation Outcomes in Tourism. In: R Phillips \& S Roberts (eds). Tourism, Planning, and Community Development. Oxon: Routledge. 35-49.

Saxena NC (2011) What is Meant by People's Participation. In: A Cornwall (ed). The Participation Reader (pp. 31-33). New York: Zed Books Ltd 